\title{
Upute za dobar govor u odgajanju i obrazovanju Nadahnute Kvintilijanovim i Marulićevim mislima
}

Jelena Vignjević* jelena.vignjevic@ufzg.hr https://orcid.org/0000-0002-0411-7615 https://doi.org/10.31192/np.18.2.7

UDK: $808.5: 37$

005.336.5:005.57]:37

Pregledni članak / Review

Primljeno: 13. svibnja 2020.

Prihvaćeno: 18. lipnja 2020.

U ovome radu razmišlja se o govoru u djelatnostima odgoja $i$ obrazovanja te o govornim sposobnostima potrebnima odgojitelju, učitelju i nastavniku za uspješno upućivanje djece $i$ mladih ljudi u proces stjecanja znanja, ali $i$ vrlina potrebnih za dobar život i suživot s drugima. Pritom se na odgojiteljev (učiteljev, nastavnikov) govor gleda kao na jedinstvo dviju njegovih nerazdvojnih sastavnica - komunikacijske i retoričke. Ističe se, danas često zanemarena, potreba njegovanja i retoričke sastavnice odgojiteljskoga govora, ne samo komunikacijske. U tom se kontekstu donose izabrani retorički naputci za govor u odgoju i obrazovanju, oprimjereni mislima rimskoga retoričara Kvintilijana te europskoga $i$ hrvatskoga kršćanskoga humanista Marka Marulića.

Ključne riječi: govor, komunikologija, odgojitelj, odgoj i obrazovanje, retorika.

»Ugodan i razuman govor dar je prirode, ali može se i steći. Svakako je to više stvar formalna, predmet uzgoja i navade. Nije dosta, da učiš gramatiku, sintaksu i stilistiku, treba u prvom redu samorada, discipline uma i duha, čuvstva i htijenja. ${ }^{1}$

\footnotetext{
* Doc. dr. sc. Jelena Vignjević, Sveučilište u Zagrebu, Učiteljski fakultet, Savska cesta 77, HR10000 Zagreb.

${ }^{1}$ Jagoda TRUHELKA, $U$ carstvu duše. Odgojni epistolar, drugo nepromijenjeno izdanje prigodom 100. obljetnice prvog izdanja (Osijek, 1910 - Zagreb, 2010), Zagreb, Naklada sv. Antuna - Nova stvarnost, 2010, 37.
} 


\section{Uvod}

Život u 21. stoljeću po mnogočemu je različit od onoga u prijašnjim vremenima, pa je različito i upućivanje djece u život, odnosno odgajanje djece. Pred odgojiteljima ${ }^{2}$ danas je nimalo lak zadatak odgovaranja na potrebe djece, ${ }^{3}$ roditelja i društva u doba i za doba globalne umreženosti, brzih promjena, novih medija, naglašenog individualizma itd. Ističe se stoga važnost stjecanja brojnih kompetencija pri odgojiteljskoj edukaciji, od didaktičkih vještina u radu $\mathrm{s}$ djecom do vještine samorefleksije u promišljanju i unaprjeđenju vlastitoga rada. No koliko god se odgojiteljska praksa podupirala suvremenim didaktičkim sredstvima, koliko god se za djecu osiguravala poticajna i bogata materijalna okolina, ipak ostaje kao temeljno i neizostavno sredstvo odgojiteljskog rada ono isto kojim se odgajalo otkad je (ljudskoga) svijeta i vijeka, a to je riječ. Odgajati i podučavati djecu znači govoriti im i razgovarati s njima. Živa riječ, poticajna za onoga komu je pućena, nije do danas nimalo izgubila na važnosti u procesu odgoja. Ipak, malo se govori o presudnoj važnosti riječi i razgovora u procesu odgajanja. Izgleda da se te fenomene poima toliko temeljno ljudskima, da se oni na neki način podrazumijevaju, doživljavaju se kao nešto samo po sebi razumljivo, kao ono na što se računa i kad se o tome ne govori. No je li to tako? Jesu li odgojitelji danas svjesni snage svoje riječi, osjećaju li samopouzdanje u vlastitim govornim vještinama, znaju li oblikovati svoj govor tako da on bude primjeren odgojnoj situaciji, poticajan za dijete i uzorit za dječji govor te da bude sredstvo izgradnje pozitivnih međuljudskih odnosa u odgojnim i obrazovnim ustanovama? Ta i slična pitanja pokretač su svega razmišljanja $u$ ovome radu. Bez namjere da se na njih odgovori, ali sa željom da se dade prinos razumijevanju govorničke i komunikacijske sastavnice odgojiteljskoga rada.

Odgojiteljevo djelovanje zahtijeva visoku razinu govorničkih i komunikacijskih sposobnosti, što je za odgojitelje izazovno, ali i vrlo zahtjevno, pa i teško. To potvrđuju brojna istraživanja među odgojiteljima u svijetu, a i manje brojna domaća istraživanja. ${ }^{4}$ Odgojitelji izvješćuju o tome da im nedostaje znanja, pa posljedično i samopouzdanja, u brojnim komunikacijskim situacijama, a posebno u organizaciji i provedbi roditeljskih sastanaka te $u$ komunikaciji s roditeljima. Većina ispitanika iskazala je potrebu dodatne edukacije u govorničkom

${ }^{2}$ Riječ odgojitelj u ovom se tekstu odnosi kako na odgojitelje tako i na odgojiteljice, ali i na učitelje i učiteljice te na nastavnike i nastavnice.

${ }^{3}$ Riječ dijete u ovom se tekstu odnosi na djecu rane i predškolske dobi, obaju spolova, ali i na djecu školske dobi, tj. učenike i učenice.

${ }^{4}$ Usp. Marina PAVLOVIĆ, Komunikacija odgojitelja s roditeljima na roditeljskom sastanku, diplomski rad, Zagreb, Učiteljski fakultet Sveučilišta u Zagrebu, 2019; Ana BRČIĆ JAKOVINA, Svijest odgojitelja o uporabi standardnoga govora pri odgoju djece, diplomski rad, Zagreb, Učiteljski fakultet Sveučilišta u Zagrebu, 2019; Sanja BEŽEN, Mišljenje odgojitelja o upotrebi standardnoga hrvatskog jezika u dječjim vrtićima, diplomski rad, Zagreb, Učiteljski fakultet Sveučilišta u Zagrebu, 2015. 
i komunikacijskom području. Da je osnaživanje odgojitelja za govorničke i komunikacijske aktivnosti potrebno provoditi od početka njihove akademske naobrazbe, pokazuje i ispitivanje ${ }^{5}$ provedeno među studentima na Pedagoškom fakultetu Sveučilišta u Ljubljani. Ispitivani su stavovi studenata, budućih učitelja, o zahtjevnosti govora i komunikacije u njihovoj profesiji, o tome koliko ih akademska naobrazba priprema za to i imaju li prilike za stjecanje govorničkog iskustva. Pokazalo se da su studenti svjesni važnosti govorničkih i komunikacijskih vještina u odgojiteljskoj i učiteljskoj profesiji te da smatraju da im je potrebno više znanja i iskustva u tom području negoli što ga steknu tijekom studija. Kad mladi ljudi započnu sa svojom odgojiteljskom praksom, osjećaju taj nedostatak osposobljenosti u govorničkim i komunikacijskim vještinama, pa ne čudi da se i u svijetu i kod nas nude programi usavršavanja i tečajevi za dodatnu edukaciju odgojitelja i učitelja u području komunikacije i govorništva. U razumijevanju navedenih pojava i u pokušaju da se dade prinos unaprjeđenju odgojiteljske prakse valja krenuti od razumijevanja okvira mišljenja u pogledu govora odgojitelja u odgojno-obrazovnoj djelatnosti, o čemu će biti riječi u nastavku.

\section{Odgojiteljev govor s komunikacijskoga i retoričkoga gledišta}

Odgojiteljeve riječi, njegov govor upućen djeci ili drugim dionicima odgoja i obrazovanja te njegov razgovor s djecom i drugima, danas se znanstveno promišljaju uglavnom u okviru pedagoške komunikologije, gdje se na njih gleda kao na sredstvo komunikacije kojim se grade međuljudski odnosi u procesu odgoja i obrazovanja i kojim se, izgrađujući odnos suradnje i zajedništva, djeci prenosi znanje, stavovi, ideje. Tako je od 20. stoljeća nadalje. No prije toga vremena, s početkom još u antičko doba, riječ, govor i razgovor u odgoju i obrazovanju bili su predmetom retorike gdje se na njih gledalo kao na sredstvo kojim se djecu i druge uvjerava u ideje, stavove i znanje te kojim se podučava i poučava.

Danas poznavanje govorničkih vještina nije sustavno uključeno u naobrazbu odgojitelja i učitelja. Dakako da je važno u obrazovanju odgojitelja njegovati njihov govor s komunikacijskog aspekta, naglašavati potrebu poštovanja općih komunikacijskih kvaliteta govora (razumljivost, djelotvornost, prikladnost), ${ }^{6}$ kao i nužnost odnosa suradnje $u$ komunikaciji te aktivnoga slušanja učenika i roditelja kao partnera u odgojnom procesu. ${ }^{7}$ No to je samo jedna sastavnica odgojiteljeva govora. Druga je sastavnica ona retorička, bez njezina poznava-

\footnotetext{
${ }^{5}$ Usp. Tomaž PETEK, Ozaveščenost o javnem govornem nastopanju. Priložnost za profesionalni razvoj učitelja, Jezik in slovstvo, 57 (2012) 3-4, 115-129.

${ }^{6}$ Usp. Kathleen K. REARDON, Interpersonalna komunikacija. Gdje se misli susreću, Zagreb, Alineja, 1998.

${ }^{7}$ Usp. Smiljana ZRILIĆ, Kvaliteta komunikacije i socijalni odnosi u razredu, Pedagogijska istraživanja, 7 (2010) 2, 231-242.
} 
nja govor ostaje bez onih sredstava kojima će slušatelja uvjeriti i oduševiti, a govornik ostaje bez potrebnog mu alata u promišljanju, sastavljanju i izricanju svoga obraćanja slušatelju. Ne samo komunikacijsku, već i retoričku sastavnicu govora valja njegovati da bi govor u odgoju i obrazovanju postizao svoju svrhu, a odgojitelj da bi bio uspješan poučavatelj, komunikator i kreator zdrava i poticajna ozračja u svojoj odgojno-obrazovnoj zajednici.

Najprije ukratko o današnjem, suvremenom, znanstvenom okviru za razmišljanje o odgojiteljevu govoru, a potom o retoričkomu.

\subsection{Odgojiteljeva riječ kao predmet komunikologije}

O odgojiteljevu govoru promišlja se unutar znanstvenoga područja pedagoške komunikologije ${ }^{8}$ kao jedne od grana komunikologije. Govor i razgovor odgojitelja i drugih dionika u odgoju i obrazovanju razumijevaju se kao komunikacijske vještine koje, kao i sve ostale vještine što se rabe u međuljudskim odnosima (engl. interpersonal skills), ${ }^{9}$ uključuju proces u kojem pojedinac provodi skup ciljanih, međusobno povezanih i situaciji prilagođenih oblika ponašanja, koji se uče i kontroliraju.$^{10}$ Dakle, odgojiteljeva komunikacija razumijeva se znatno šire od samoga govora i riječi, ona uključuje sve neverbalne i verbalne oblike ponašanja kojima odgojitelj, u određenim komunikacijskim okolnostima, sugovornicima i suradnicima prenosi poruke. Situaciju kojom je ta komunikacija određena čine okolnosti procesa odgajanja, učenja i poučavanja u odgojno-obrazovnoj ustanovi (dječjem vrtiću ili školi).

Drugim riječima, odgojiteljev govor zadan je njegovom profesionalnom ulogom institucijskog odgajanja i poučavanja i može se na nj gledati iz različitih vidova. Tako se, s obzirom na sugovornika u komunikaciji, razlikuje odgojiteljeva komunikacija s djecom (u poučavanju, upućivanju, objašnjavanju, tumačenju i sl.), s roditeljima djece (roditeljski sastanci, informativni razgovori s roditeljima i sl.) te sa suradnicima i kolegama u odgojno-obrazovnoj ustanovi (s drugim odgojiteljima, s ravnateljem, sa stručnim suradnicima, s drugim zaposlenicima ustanove).

Moguće je, funkcionalno i situacijski gledano, reći kako se odgojiteljev govor ili pedagoški govor (engl. pedagogical speech) ostvaruje u dvama oblicima - kao instrukcijski govor (engl. instructional speech) i kao relacijski govor (engl. rela-

\footnotetext{
${ }^{8}$ Usp. Pavao BRAJŠA, Pedagoška komunikologija - razgovor, problemi i konflikti u školi, Zagreb, Školske novine, 1993; Marija BRATANIĆ, Mikropedagogija. Interakcijsko-komunikacijski aspekt odgoja, Zagreb, Školska knjiga, 1991.

9 Usp. Megan K. FALEY, Steve DUCK, Relational Communication, u: Owen HARGIE (ur.), The Handbook of Communication Skills - third edition, New York, Routledge, 2006, 427-450.

${ }^{10}$ Usp. Owen HARGIE, Skill in theory. Communication as skilled performance, u: Owen HARGIE (ur.), The Handbook of Communication Skills - third edition, New York, Routledge, 2006, 7-36, 13.
} 
tional speech). ${ }^{11}$ Instrukcijskim se govorom odgojitelj koristi pri obrazovanju djece, tj. pri prijenosu kojega sadržaja djeci, pri podučavanju i provjeravanju naučenoga, tumačeći i opisujući što, postavljajući pitanja, razgovarajući s djecom o čemu i sl. Relacijskim se govorom odgojitelj koristi pri odgoju djece, tj. u komunikaciji s djecom pri izgradnji njihovih međusobnih odnosa (u dogovorima, razmiricama, nesporazumima...), pri nastojanju da ih uputi u vrline i moralne vrijednosti (u poučavanju), pri izgradnji vlastitoga odnosa s djetetom/djecom, ali i pri izgradnji odnosa s roditeljima djece koju odgaja te pri izgradnji odnosa sa suradnicima i kolegama.

Promatranje odgojiteljeva govora kao jedne od njegovih komunikacijskih vještina, kojima se stvaraju i raskidaju međuljudski odnosi, najčešće rezultira time da se odgojitelje upućuje na govor kojim će graditi pozitivne međuljudske odnose sa svim dionicima odgojno-obrazovnog procesa te tako pridonijeti zdravu ozračju i dobrim odnosim u dječjem vrtiću ili školi. Sve se češće upravo u odnosima gleda ključ uspjeha odgoja i obrazovanja i ističe se potreba njegovanja dobrih međuljudskih odnosa djece i djece, djece i odgojitelja, odgojitelja i roditelja, odgojitelja i odgojitelja (kolega, suradnika, ravnatelja). Naime, njegovanje zajedništva u odgojno-obrazovnoj ustanovi i brižan odnos jednih prema drugima stvorit će pozitivno i poticajno ozračje za rad, za učenje, podučavanja i odgajanje. Stoga se sve češće unutar pedagogije odnosa ${ }^{12}$, kao podloge promišlja o promjenama, govori o unaprjeđenju i poboljšanju odgoja i obrazovanja.

\subsection{Odgojiteljeva riječ kao predmet retorike}

Uz razumijevanje odgojiteljeva govora u opisanom kontekstu (pedagoške) komunikologije, valja se podsjetiti na retoričke sastavnice govora u odgoju i obrazovanju, kao i na retoričko tumačenje i razumijevanje odgojiteljeva govora. Retorika je umijeće govorenja i uvjeravanja, ali i teorija govorenja ${ }^{13}$ pa ne čudi da je odgojiteljev govor bio, i do danas ostao, predmetom proučavanja u okvirima retorike kao teorije govorenja. Odgojitelj jest javni govornik, i to po brojnim odlikama. ${ }^{14}$ Prije svega, koje god vrste bio odgojiteljev govor te bio on upućen djetetu, roditelju ili suradniku, odgojitelj njime želi drugoga uvjeriti, prenijeti mu spoznaje, stavove, ideje. Nadalje, i javni govornik i odgojitelj imaju pred sobom publiku kojoj se obraćaju, i jedan i drugi pripremaju se za prenošenje određenog sadržaja publici, i jednom i drugom stalo je do toga da uvjere publiku u ono što joj prenose, da ostave na publiku pozitivan dojam, da ih publika

\footnotetext{
${ }^{11}$ Usp. Tomaž PETEK, The Teacher as a Public Speaker in the Classroom, Studies in Literature and Language, 9 (2014) 1, 124-133.

${ }^{12}$ Usp. Vesna BILIĆ, Slavica BAŠIĆ, Odnosi u školi. Prilozi za pedagogiju odnosa, Zagreb, Učiteljski fakultet Sveučilišta u Zagrebu, 2016.

${ }^{13}$ Usp. Retorika, Hrvatska enciklopedija, mrežno izdanje, Leksikografski zavod Miroslav Krleža, http://www.enciklopedija.hr/Natuknica.aspx?ID=52577 (04.05.2020).

${ }^{14}$ Usp. Petek, The Teacher as a Public Speaker in the Classroom..., 125-126.
} 
zapamti. Po tome su u odgojiteljevu govoru zastupljene sve tri Aristotelove (4. st. pr. Krista) temeljne odlike retoričkoga čina: smislenost i logičnost govornikova mišljenja i govora (grč. logos), vjerodostojnost sama govornika (grč. ethos) i dojmljivost njegova govora (grč. pathos). Naposljetku, odgojitelj u pripremanju za podučavanje djece prolazi pet retoričkih koraka: 1) odabir sadržaja poučavanja i prikupljanje građe (lat. inventio), 2) raspoređivanje prikupljenoga u slijed kojim će se izreći (lat. dispositio), 3) jezično oblikovanje sadržaja (lat. elocutio), 4) pamćenje sadržaja (lat. memoria), 5) izricanje sadržaja, tj. glasovna i gestovna prezentacija sadržaja (lat. pronuntiatio). ${ }^{15}$ Sve navedeno dolazi do izražaja i $\mathrm{u}$ instrukcijskom i u relacijskom govoru odgojitelja, odnosno i onda kada odgojitelj njime podučava djecu (kad im što objašnjava, argumentira, tumači) i onda kad se svojim govorom usmjerava na njihov odgoj (npr. na uvjeravanje radi izgradnje pozitivnih odnosa među djecom) i onda kada je pred njim zadatak govorenja pred roditeljima djece (npr. na roditeljskom sastanku). Potonje, možda i više od ostalih aktivnosti, od odgojitelja traži dobra govornika, odnosno poznavanje retoričkih zakonitosti. ${ }^{16}$

Dakako, postoje i značajne razlike između javnoga govorenja i odgajanja ili podučavanja, a najočitija je razlika u publici, odnosno u vezi koju odgojitelj izgrađuje sa svojom publikom - djecom. Odgojitelj govori publici koja mu je povjerena na brigu i odgoj te svoj govor prilagođuje spoznajnim mogućnostima, predznanju i sposobnostima svoje publike, odnosno djece. ${ }^{17}$

Klasična je retorika, kako grčka tako i rimska, na odgojiteljev pedagoški govor ostavila izniman trag, i danas prepoznatljiv, a u tome se posebno izdvaja djelo rimskoga retoričara Marka Fabija Kvintilijana (1. st.) zahvaljujući kojemu je retorika u okrilje svoga bavljenja uzela i područje poučavanja, odnosno odgoja i obrazovanja. S Kvintilijanovim Obrazovanjem govornika ${ }^{18}$, traktatom u kojem su sadržana pedagoška i didaktička načela primjenjiva na odgojno-obrazovnu praksu uopće, ne samo na govorničku, retorika postaje sveobuhvatan odgojno-obrazovni program.

Tijekom srednjega vijeka retoričke su se spoznaje, iako sužene, koristile u brojnim djelatnostima i sferama života, od opismenjavanja i školovanja pa do propovijedanja. Upravo je umijeće propovijedanja (lat. ars praedicandi), utemeljeno na klasičnim retoričkim spoznajama, retoriku dalje razvijalo i učvršćivalo.

\footnotetext{
${ }^{15}$ Usp. Jasna ŠEGO, Kako postati uspješan govornik. Priručnik retorike za učenike i studente, Zagreb, Profil, 2005, 11; Ivo ŠKARIĆ, Temeljci suvremenog govorništva, Zagreb, Školska knjiga, 2000.

${ }^{16}$ Usp. Željka ŽIVKOVIĆ, Susreti s roditeljima I. Priručnik za održavanje roditeljskih sastanaka, Đakovo, Tempo, 2005.

${ }^{17}$ Usp. Derek FEATHERSTONE, The difference between speaking and teaching (08.01.2014), http://seizetheroom.com/articles/differences/ (28.04.2020).

${ }^{18}$ Usp. Marko Fabije KVINTILIJAN, Obrazovanje govornika. Odabrane strane, s lat. preveo, predgovor i komentar napravio Petar Pejčinović, Sarajevo, Veselin Masleša, 1995.
} 
Duh humanizma i renesanse koji je, krenuvši u 14. stoljeću iz talijanskih akademskih središta, zahvatio Europu, donio je i renesansu retorike kao vještine i kao predmeta poučavanja kojim će se, kao jednim od predmeta obuhvaćenih novim obrazovnim konceptom i sustavom humanističkih studija (lat. studia humanitatis), postići svrha svega odgoja i obrazovanja (kojoj je u temeljima Ciceronova ideja), a to je razvoj punog ljudskog potencijala mladog čovjeka. ${ }^{19}$ Novo humanističko obrazovanje stavlja naglasak na njegovanje etičkih i retoričkih vrijednosti (koristeći se pritom ponajviše Ciceronovim i Kvintilijanovim djelima), ${ }^{20}$ ali u duhu kršćanstva. Humanizam je po tome i obnova grčkih i latinskih autora kao nadahnuća za novu spoznaju, ali i nastavak misli srednjovjekovnih autora. ${ }^{21}$ Kao intelektualni pokret on se temeljio na spomenutom programu humanističkih studija (koji je uključivao gramatiku, retoriku, poeziju, povijest i moralnu filozofiju) i ostavio je dubok trag na brojnim područjima renesansnoga, ali i kasnijega europskog društva: na području likovne umjetnosti, glazbe, znanosti, pravne i političke teorije, teologije... ${ }^{22} \mathrm{U}$ području obrazovanja taj je utjecaj možda i najočitiji i najdublji, pa se i danas - kad se govori o konceptu humanističkog obrazovanja - misli upravo na obrazovanje sa svrhom koju su isticali humanisti, a to je obrazovanje s nakanom formiranja čestita, plemenita i skladna čovjeka, opremljena kako intelektualnim tako i moralnim vrijednostima.

Retorika u konceptu humanističkog obrazovanja ima stožernu ulogu pa će ostati više ili manje prisutna u obrazovnom kanonu sve do konca 19. stoljeća, otkad će postupno iščezavati iz obrazovanja, ponajviše zbog specijalizacije i preustroja sustava znanosti.

Ovaj kratak uvid u retoriku i njezin put kroz odgoj i obrazovanje, s naglaskom na retoriku u klasičnoj kulturi i u kulturi renesansnog humanizma, uvod je za daljnji tekst u kojem će se iz tih dvaju kulturnih krugova, kao izvorišta današnjega europskoga sustava obrazovanja, izdvojiti nadahnuća za razmišljanje o govoru odgojitelja.

\section{Govor u odgajanju i obrazovanju (po Kvintilijanovim $i$ Marulićevim primjerima)}

Ovaj izbor retoričkih naputaka vrijednih za odgojitelje kao govornike počiva na klasičnomu, već spomenutomu, Kvintilijanovu djelu Obrazovanje govornika (Institutio oratoria) te na djelu hrvatskoga kršćanskoga humanista Marka

\footnotetext{
${ }^{19}$ Usp. Charles G. NAUERT, Humanism and the Culture of Renaissance Europe, Cambridge, Cambridge University Press, 2006.

${ }^{20}$ Usp. Robert BLACK, Humanism and Education in Medieval and Renaissance Italy, Cambridge, Cambridge University Press, 2003.

${ }^{21}$ Usp. Paul Oscar KRISTELLER, Renaissance Thought and the Arts, Collected Essays, New Jersey, Princeton University press, 1980.

${ }^{22}$ Isto.
} 
Marulića (15. i 16. st.) Upućivanje u čestit život po primjerima svetaca (De institutione bene vivendi per exempla sanctorum $)^{23}$ - knjizi za koju se u nas ustalio naziv Institucija, a koja je uživala iznimnu popularnost i ugled te doživjela više desetaka izdanja širom Europe i na mnogim jezicima.

Kvintilijanovo je djelo izbrano za ovu temu zbog njegova prinosa europskomu obrazovanju i pedagoškoj misli, a iznad svega zbog dviju njegovih važnih poruka: prva je da "samo čestit i valjan čovjek može biti govornik « ${ }^{24}$ (lat. Nemo orator nisi vir bonus), a druga je da se dobar govornik odgaja, ne samo podučava, i to od ranog djetinjstva. On ističe u tome važnost djetetovih dojilja (uz roditelje, djetetovih prvih odgojitelja) kao moralnoga i govornog uzora za dijete:

»Bez sumnje najveću pažnju treba obratiti na njihov moralni lik, ali one moraju i pravilno govoriti. Njih će dijete najprije slušati, njihove će riječi kušati imitirati i podražavati. Od prirode najbolje pamtimo što smo u se usisali u nerazvijenoj dobi, slično posudama koje zadržavaju onaj okus kojim su prvi put bile napunjene, ili vunenim tkaninama s kojih se ne mogu skinuti boje kojima je njihovo prirodno bjelilo bilo obojeno. « ${ }^{25}$

Spomenute će Kvintilijanove temeljne ideje objeručke prihvatiti humanisti koji iznimno cijene govorničke vještine, a ljudske vrijednosti i ljudsko dostojanstvo temeljne su im tematske preokupacije. To je došlo do izražaja i u djelu kršćanskog humanista Marka Marulića, koji humanističke ideje donosi s jakim biljegom kršćanskog duha i kršćanskih vrijednosti, a što je vidljivo i u, kako navodi Lučin, ${ }^{26}$ njegovu zalaganju za odgoj »u strahu Božjem « i za obrazovanje $\mathrm{u} »$ plemenitijim naukama«, ${ }^{27} \mathrm{tj}$. književno obrazovanje temeljeno na čitanju antičkih pisaca.

Izabrano Marulićevo djelo, Institucija, tematski je organizirana knjiga uputa, pouka i primjera za krepostan život u kojoj Marulić pouke i putokaze oprimjeruje citatima, likovima i primjerima iz kršćanske literature, prije svega iz Biblije i djela kršćanskih otaca. Marulićev izbor ranokršćanskih pisaca Lučin tumači ovako:

»Grčki i latinski ranokršćanski pisci humanistima su bili zanimljivi upravo stoga što su teološke teme izlagali školovanim jezikom antičke retorike te stoga što su nastojali djelovati emocionalno na svoje čitatelje, potaknuti ih na djelatne promjene u životnim načelima i u ponašanju. $\ll^{28}$

\footnotetext{
${ }^{23}$ Marko MARULIĆ, Upućivanje u čestit život po primjerima svetaca (izvornik: Marci Maruli, De institutione bene vivendi per exempla sanctorum, prvo poznato izdanje 1507.), s latinskoga na hrvatski preveo, komentirao i priredio Branimir Glavičić, Nakladni zavod Globus, Zagreb, 2010.

${ }^{24}$ Kvintilijan, Obrazovanje govornika..., 490.

${ }^{25}$ Isto, 45

${ }^{26}$ Bratislav LUČIN, Studia humanitatis u Marulićevoj knjižnici, Colloquia Maruliana, 6 (1997) 169-203.

${ }^{27}$ Isto, 171 .

${ }^{28}$ Isto, 200.
} 
Premda nijedan dio izabrane Marulićeve knjige nije izravno upućen odgojiteljima ili učiteljima, ona je izabrana, uz Kvintilijanovu, kao vrelo za promišljanje o govoru odgojitelja jer mnoge upute (npr. iz 4. poglavlja »O dužnosti naučavatelja evanđelja« i iz 6. poglavlja »O šutljivosti i umjerenosti u govoru«) mogu biti putokaz onomu tko podučava i odgaja. Zaista, iako se Marulić obraća naučavateljima evanđelja, obraća se i svima drugima koji »neuke upućuju, bojažljive bodre, a lijene gone ${ }^{29}{ }^{29}$

Tekst koji slijedi donosi deset naputaka za govor odgojitelja, koje nadahnuće crpe na iskonima europskoga odgoja i obrazovanja utemeljenima u klasičnoj kulturi i u kršćanskoj humanističkoj kulturi.

\subsection{Odgojiteljeva je riječ vjerodostojna}

Vjerodostojnost govornika, pa i odgojitelja, nužna je da bi njegov govor bio prihvaćen i da bi postigao svoj cilj. U riječi vjerodostojan jasno je vidljivo njezino značenje - vjerodostojan je onaj koji je dostojan da mu se povjeruje, a vjeruje se onome čiji je govor usklađen s djelovanjem, kojemu verbalni iskaz nije u sukobu s neverbalnim, koji i sam svjedoči ono što govori. To potvrđuje i zakonitost učenja po modelu ili učenja od uzora. Jedna od značajki onoga tko će djeci biti prihvatljiviji kao uzor za oblikovanje vlastitog ponašanja jest usklađenost riječi i ponašanja: vjerodostojniji će biti onaj uzor koji i sam radi ono što zagovara. ${ }^{30}$ Presudnu važnost vjerodostojnosti onoga koji poučava, ističe i Marulić:

"Onaj naime tko je spreman ispravljati ono što je nevaljalo u drugih, mora biti bez ikakve grješke kako bi ne samo riječima nego i primjerom potakao slušatelje da poprave svoj život. « ${ }^{31}$

\subsection{Odgojiteljeva je riječ stručna (kompetentna)}

Kvintilijan je postojećim zahtjevima da govornik mora biti častan, neporočan čovjek (lat. vir bonus dicendi peritus) dodao i zahtjev da govornik mora biti mudar čovjek, da mora dobro poznavati ono o čemu govori, pa se zalaže za sustavno obrazovanje budućih govornika još od rane dobi. I odgojitelju (učitelju, nastavniku, profesoru), koji govorom podučava djecu (učenike, studente) čemu, treba široka naobrazba i vrhunsko znanje toga čemu ih podučava. Treba mu i znanje o podučavanju samomu (znanje o tome kako podučavati). I za sam govor odgojitelju treba znanje. Treba poznavati odlike dobra govora, treba se znati izražavati u skladu sa standardnojezičnom normom, treba poznavati stil-

\footnotetext{
${ }^{29}$ Marulić, Upućivanje u čestit život po primjerima svetaca..., 180.

${ }^{30}$ Usp. Laura E. BERK, Dječja razvojna psihologija, ur. hrv. izd. Gordana Keresteš, Jastrebarsko, Naklada Slap, 2015.

${ }^{31}$ Marulić, Upućivanje u čestit život po primjerima svetaca..., 180.
} 
ske odlike jezičnoga izražavanja. Nije to važno samo zbog toga što odgojiteljev govor, da bi bio dobar govor, treba imati tri temeljne odlike: jezičnu pravilnost, jasnoću i ljepotu, već i zbog toga što je odgojiteljev govor uzor po kojemu će dijete oblikovati vlastiti govor. Kvintilijan nekoliko poglavlja svoje knjige posvećuje isticanju važnosti govorničke, stručne i moralne izvrsnosti onih koji dijete odgajaju i podučavaju, ali i samih djetetovih roditelja: »Moja je vruća želja da i roditelji budu što obrazovaniji. Pri tome ne mislim samo na očeve.« $^{32}$ Višekratno Kvintilijan ističe potrebu jedinstva stručnosti (kompetentnosti) i moralnosti odgojitelja:

»Učitelj treba da se jednako odlikuje svojim govorničkim sposobnostima i moralnim kvalitetima i treba da je sličan Homerovom Feniksu kako bi mogao istovremeno učiti svoje učenike kako će govoriti i kako će se ponašati.« ${ }^{33}$

Marulić također ističe važnost naučavateljeve naobrazbe i izvrsna poznavanja onoga o čemu govori, savjetujući: »Dugo uči o čemu ćeš druge učiti.« ${ }^{34}$

\subsection{Odgojiteljeva riječ poštuje dijete i njegovo ljudsko dostojanstvo}

Da odgojitelj djetetu mora pristupati kao jednakovrijednu čovjeku poštujući njegovo ljudsko dostojanstvo, napominje i Kvintilijan oštro osuđujući kažnjavanje djece i zamjerajući onima koji to odobravaju na dvostrukim kriterijima kad isto ponašanje nad odraslim kategoriziraju kao nasilje, a nad djetetom kao odgajanje:

»U svakom slučaju to je nasilje, što bi svako priznao kada bi žrtva šibanja bio čovjek starije dobi. (...) Neka mi bude dozvoljena ova primjedba: niko ne bi smio imati neograničenu slobodu nad ovom slabom i nasilju izloženoj dobi.«35

Pri ukazivanju na pogreške odgojitelj također treba poštovati dijete i paziti da ga riječima ne povrijedi:

»U popravljanju grešaka ne smije biti zajedljiv, naročito uvredljiv. Mnogi su napustili započete studije zato što neki dijele ukore na taj način kao da na prestupnicima iskaljuju svoju mržnju. «

Iz duha poštovanja djeteta proizaći će i duh suradnje, nužan za uspjeh odgajanja i obrazovanja, jer, Kvintilijanovim riječima, »govorništvo može samo uspijevati u skladnoj suradnji onoga koji uči i onoga koji podučava«. ${ }^{37}$

\footnotetext{
${ }^{32}$ Kvintilijan, Obrazovanje govornika..., 45.

${ }^{33}$ Isto, 128.

${ }^{34}$ Marulić, Upućivanje u čestit život po primjerima svetaca..., 188.

${ }^{35}$ Kvintilijan, Obrazovanje govornika..., 60-61.

${ }^{36}$ Isto, 125.

${ }^{37}$ Isto, 145.
} 


\subsection{Odgojiteljeva je riječ jasna}

Jasnoća govora jedan je od temeljnih i istaknutih retoričkih zahtjeva. Da bi dopro do onoga komu je upućen, tj. da bi ga taj razumio i zapamtio, govor mora biti jasan. Kvintilijan upozorava na čestu pojavu nejasna govora kod vrlo obrazovanih ljudi, a koju se obično opravdava stručnim metajezikom, specijaliziranim znanjem i sl. No nije riječ samo o izrazu, već i o strukturiranju misli i logičnosti mišljenja, a upravo u to upućuje retorika kao vještina. Kvintilijan ističe:

»Čest je slučaj da su predavanja najučenijeg učitelja laka za razumijevanje i mnogo jasnija. Osnovna vrlina govorničke vještine je jasnoća, a što je ko manje duševno nadaren, to će nastojati da se više uzdigne i da se naširoko raspriča, isto kao što se niski rastom izdižu na prste... Što je ko lošiji kao učitelj, to će biti teži za razumijevanje. ${ }^{38}$

\subsection{Odgojiteljeva je riječ blaga}

Strogosti nije mjesto u odgoju i obrazovanju. Kvintilijan to višekratno ističe. Npr.:

»Dobro je također upozoriti učitelja da velika strogost $\mathrm{u}$ ispravljanju pogrešaka može katkada da obeshrabri dječake. Oni izgube samopouzdanje, sekiraju se i na kraju zamrze i sam posao... Zato prema ovoj dobi treba da je učitelj do krajnosti obazriv i blag. (39 $^{39}$

Na blagost pri poučavanju drugih poziva i Marulić. Potrebu za blagom riječju oprimjeruje navodima iz Biblije: "Blaga je besjeda drvo života, a koja je neumjerena, satrt će dušu» (Izr 15,4). ${ }^{40}$ »Starca ne grdi, nego ga opomeni kao oca, mladiće kao braću, starice kao majke, a djevojke kao sestre u svoj čistoći« (1 Tim 5,1-2). ${ }^{41}$ »Ako upadne tko u kakav grijeh, vi duhovni ljudi ispravljajte toga u duhu blagosti« (Gal 6,1). ${ }^{42}$

\subsection{Odgojiteljeva je riječ primjerena dobi i osobnim odlikama djeteta}

Kvintilijan slikovito ističe da i učenje ima svoje djetinjstvo. Sadržaje poučavanja, pa i riječi kojima se djecu u njih upućuje, kao i one kojima ih se odgaja, valja prilagoditi dobi djeteta. »Neka prve njegove pouke budu u obliku igre.

\footnotetext{
${ }^{38}$ Isto, 128.

${ }^{39}$ Isto, 130-131.

${ }^{40}$ Marulić, Upućivanje u čestit život po primjerima svetaca..., 285.

${ }^{41}$ Isto, 187.

${ }^{42}$ Isto.
} 
Treba mu postaviti pitanja i hvaliti svaki njegov odgovor te podešavati da mu ono što radi pričinja radost. « ${ }^{43}$

»Učitelju mora biti prva briga kada radi sa još nerazvijenim dušama, da odmah ne opterećuje nježne mozgove svojih učenika zadacima koji su iznad njihovih umnih snaga, nego da dobro obuzda svoju energiju i da se spusti na razinu intelektualnih mogućnosti svojih slušalaca.« ${ }^{44}$

Marulić u svom djelu to izriče ovako: »Savršenijima treba davati uzvišenije pouke za život, a slabijima lakše - Mlijeko malenima, a čvrstu hranu već odraslima (Heb 5,13-14).«"

Također, važno je u svemu poštovati individualne odlike djeteta:

»Obično se smatra odlikom dobra učitelja, i to s pravom, ako kod onih koje je primio na obuku brižljivo vodi računa o razlici u umnim sposobnostima i ako zna za šta svaki pojedinac od prirode pokazuje sklonost.«46

\subsection{Odgojiteljeva je riječ pravodobna}

Vrijeme je ključna sastavnica svega života i svakog djela, pa i djela poučavanja. Odgojiteljeva riječ bit će vrijedna ako do djeteta dođe u pravo vrijeme. Ne samo do djeteta, već i do drugih sudionika u odgoju - roditelja, suradnika i dr. Na vrijednost pravovremenosti govora u poučavanju upućuje Marulić biblijskom mišlju: "Riječi izgovorene u pravo vrijeme, zlatne su jabuke u srebrnim posudama« (Izr 25,11). ${ }^{47}$

U tom kontekstu treba se osvrnuti i na vrijednost šutnje. Dobar govornik, kao i odgojitelj, prepoznaje kad je vrijeme za govor, a kada za šutnju. Marulić ističe vrijednost mudra upravljanja govorom i riječima, što oslikava biblijskom mišlju: »Tko će postaviti stražu ustima mojim i na usne moje staviti pečat razboritosti da ne posrnem zbog njih i da me moj jezik ne uništi?« (Sir 22,27). ${ }^{48}$ Ali i dodaje:

»Međutim, da ne bi tko mislio da zbog toga vrijedi uvijek šutjeti neka čuje Izaiju kako jadikuje: Jao meni - veli - jer sam šutio (Iz 6,5)... Prorok, naime, uviđa da je zavrijedio prijekor što nije izgrdio kralja Uziju i narod koji je srljao naglavce u poroke (Sir 4,23). $^{49}$

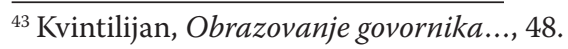

${ }^{44}$ Isto, 57.

${ }^{45}$ Marulić, Upućivanje u čestit život po primjerima svetaca..., 182.

${ }^{46}$ Kvintilijan, Obrazovanje govornika..., 148.

${ }^{47}$ Marulić, Upućivanje u čestit život po primjerima svetaca..., 285.

${ }^{48}$ Isto, 283.

${ }^{49}$ Isto.
} 


\subsection{Odgojiteljeva riječ ne laska}

Odgojiteljeva riječ, bila ona upućena djetetu ili djetetovu roditelju, treba biti iskrena. Marulić potrebu za iskrenošću naglašava kao važnu u svakom poučavanju:

»Dolikuje, naime, da naučavatelj bude daleko od svakog ulagivanja. Čovjek koji laskavim i hinjenim riječima govori svome prijatelju, razapinje mrežu njegovim koracima (Izr 29,5). Jer laskavac ne obuzdava nevaljalce dok im se ulaguje, nego ih čini još slobodnijima. Toj će se pogrješci lako ukloniti tko svemu pretpostavi istinu. $\ll^{50}$

\subsection{U odgojiteljevoj je riječi ljubav prema odgajanju djece}

Ništa bez ljubavi. I klasična retorika, kao i poslije sveti Augustin, ističu važnost ljubavi i žara za uspjeh govorničkoga djelovanja, za pokretanje osjećaja u drugima. Ni Kvintilijan ne zaboravlja istaknuti važnost učiteljeve ljubavi prema poučavanju, pa kaže: »Dobar učitelj (...) na svoj nastavnički poziv ne gleda kao na dužnost, nego kao na posao koji mu leži na srcu. ${ }^{51} \mathrm{Ni}$ danas, dvadeset stoljeća nakon Kvintilijana, nije naodmet pripomenuti: »Samo onaj koji poučava sa strašću može očekivati da njegovi učenici uče s užitkom. « ${ }^{52}$

\subsection{Odgojitelj je odgovoran za svoju riječ}

Na kraju, kao deseta među uputama, neka je i misao o odgojiteljevoj odgovornosti za riječ, za govor kojim odgaja i podučava djecu te kojim se obraća djeci, roditeljima, suradnicima i javnosti. Potrebno je govoriti o odgovornoj uporabi riječi jer riječi su vrlo moćne.

»Našom riječju, odnosno govorom, mi mnogo toga možemo učiniti. Kad nešto kažemo, onda to ima sasvim određeno djelovanje na osjećaje, misli i djelovanje drugih ljudi. Našom riječju mi tako drugome možemo pomoći da ne klone pod teretom životne sudbine, obodriti ga u njegovoj malaksalosti, otvoriti mu životnu perspektivu, ugodno ga iznenaditi, odvratiti od mržnje i osvete te potaknuti na praštanje, razumijevanje, slogu i ljubav. Riječ, odnosno govor, može dakle imati konstruktivnu ulogu među ljudima. Svi mi na žalost doživljavamo i destruktivnu posljedicu riječi i govora. «53

\footnotetext{
${ }^{50}$ Isto, 188.

${ }^{51}$ Kvintilijan, Obrazovanje govornika..., 55.

${ }^{52}$ Horge Mario BERGOGLIO, O odgoju. Izazovi za kršćanske odgojitelje, Split, Verbum, 2015, 203.

${ }^{53}$ Ivan ŠESTAK, Uvodnik: Odgovornost za riječ, Obnovljeni život - časopis za filozofiju i religijske znanosti, 56 (2001) 3, 269-270.
} 


\section{Zaključak}

Predstavljenom izboru iz dvaju kanonskih djela europske kulture - Obrazovanje govornika rimskoga retoričara Kvintilijana i Upućivanje u čestit život po primjerima svetaca hrvatskoga kršćanskoga humanista Marulića - bila je nakana pokazati kako se odgojitelji u svome govoru i u današnjim okolnostima institucijskoga odgajanja i podučavanja mogu nadahnjivati i voditi mislima iz dvaju izvora današnje europske kulture - klasičnoga i kršćansko-humanističkoga. Rad je, osim toga, ukazao i na potrebu veće prisutnosti retoričkih sadržaja u obrazovanju budućih odgojitelja i učitelja, kao i na potrebu ravnopravnog njegovanja komunikacijske i retoričke sastavnice pedagoškoga govora. Naime, odgojiteljeva svijest o odlikama dobra govora i visoka razina komunikacijskih vještina nužni su za uspješno školovanje djece, shvaćeno ne samo kao ovladavanje znanjem nego i kao stvaranje cjelovitih osoba, razvijenih kako $u$ intelektualnom tako i u emocionalnom i socijalnom području. Odgojitelj koji poznaje odlike dobra govora i odlike primjerene komunikacije u odgajanju djece, znat će za djecu stvoriti ozračje komunikacijske slobode i tolerancije, ozračje uvažavanja različitosti, jednom riječju - ozračje za razvoj pozitivnih odnosa u odgojno-obrazovnoj zajednici. Deset protumačenih naputaka za njegovanje takve komunikacije prinos je odgojiteljskoj i učiteljskoj struci, kao i obogaćivanju znanstvenoga promišljanja pedagoškoga govora kao jedinstva obiju njegovih sastavnica - retoričke i komunikacijske. Na kraju, parafrazirajući misao kojom i Kvintilijan ${ }^{54}$ završava svoju knjigu, vrijedi se nadati da će uporaba ovih pravila, ako i ne donese veliku praktičnu korist, razviti kod odgojitelja i kod djece ono što se najviše cijeni - volju da rade pošteno.

$\overline{{ }^{54} \text { Kvintilijan, Obrazovanje govornika..., }} 549$. 


\section{Jelena Vignjević* \\ Language Used in Education - Good Practice Guidance}

Summary

This paper contemplates the language used in education as well as the linguistic skills that pre-school teachers and teachers need to master so that they may introduce children, pupils and students into the process of knowledge acquisition and, no less importantly, the acquisition of the virtues one needs to have in order to lead a good life and live harmoniously with the individuals in their environment. The language of the (pre-school) teacher is here viewed as consisting of two inseparable components - communicative and rhetorical. The focus is on the need to cherish not only the communicative component of the (pre-school) teacher's language, but also the rhetorical one as the latter is often neglected in the present day and age. The rhetorical component of the (pre-school) teacher's language is exceptionally important in the instructional language used by the pre-school teacher or teacher to communicate the taught material to the students as well as in the relational speech used by the (pre-school) teacher in child nurture; i.e. in mediating when working to solve children's problems and conflicts, in creating positive relations between individuals in an educational establishment, in creating efficient relations with the parents of the children that are being cared for, etc. In the mentioned context this paper delivers good practice guidance for (pre-school) teachers related to the values good language used in education should have. The text is inspired by two canonical European masterpieces: the work of the Roman rhetorician Marcus Fabius Quintilianus Institutio oratoria ( $1^{\text {st }}$ century) and the work of the European and Croatian Christian humanist Marko Marulić Institutione bene vivendi per exempla sanctorum ( $16^{\text {th }}$ century). Many parts of the selected works are very much applicable in the education of young people today, even though centuries apart from the circumstances in which those works were created. It is shown that the fundamental values of the words a (pre-school) teacher uses when interacting with children have remained unchanged since two thousand years ago until the present day. The concept of education we have today, in which a young person acquires the knowledge they need for life as well as the virtues necessary for fruitful coexistence with the individuals in their environment, stems from classicism that has been merged with Christian values. This good language guidance exemplified by the ideas presented in the mentioned two works will contribute to the quality of the (pre-school) teacher's language used in the education of children, but also to the speech children exchange between them and all of the speech used for communication in the educational

\footnotetext{
* Jelena Vignjević, PhD, Assis. Prof., University of Zagreb, Faculty for Teacher Education; Address: Savska cesta 77, HR-10000 Zagreb, Croatia; E-mail: jelena.vignjevic@ufzg.hr.
} 
establishment. This is due to the fact that the (pre-school) teacher provides a communicational role model used by the children to shape their own communication. Children form their vocabulary and language on the basis of the vocabulary and language the (pre-school) teacher uses. Therefore, it is crucial to repetitively point to the values of good language to be used in the education of young people.

Key words: communication, education, language, (pre-school) teacher, rhetoric.

(na engl. prev. Kristina Cergol) 